\title{
The Use of Dialogic Principles of Romanian Crowdfunding Platform Communication on Facebook
}

\author{
Raluca VIDRAȘCU, PhDc \\ The Faculty of Journalism and Communication Studies (FJSC) \\ Doctoral School of FJSC \\ University of Bucharest, Romania \\ E-mail: ralu.munteanu@gmail.com
}

\begin{abstract}
This study examines how the Romanian crowdfunding platform sprijina.ro is using social media, specifically Facebook, in order to create a dialogic context for consumers, as defined by the five dialogic principles issued by Kent and Taylor (1998). To determine if dialogic communication was occurring between the organization and its followers, the content analysis method was applied to the Facebook page (posts, comments and reactions) of sprijina.ro crowdfunding platform over a 2 years span (20172019). The study attempts to answer the question of whether Romanian crowdfunding platform sprijina.ro applies the principles of dialogic communication on their Facebook page. The results show that when applying the dialogic principles, the online audience become more engaged. Unfortunately, the majority of posts analyzed ask for money donation without taking into consideration public interest or trying to engage public in the online discussion. This type of communication reflects the lack of strategy in creating and maintaining a dialogic relationship with the online audience through Facebook posts.
\end{abstract}

Keywords: Dialogic communication; Facebook; Crowdfunding; Online audience; Engagement. 


\section{Introduction}

Social networking sites have been developing really fast during the last 10 years. Networks like Facebook, Twitter or Instagram create the right context where online projects can be communicated, can meet their supporters, create and maintain a relationship with them. This aspect has been highlighted by the results of European Communication Monitor (2014) when 86\% of those interviewed considered online communication channels as being the most relevant for strategic communication, having a strong rise from $58 \%$ in 2009.

Crowdfunding campaigns depend on the online environment in order to be created, developed, communicated and promoted. Online audiences find out about crowdfunding projects through communication technologies, like mobile internet and social media, easy to be accessed through smartphones or mobile internet. Also crowdfunding campaigns rely on online communication to get media coverage, attract backers, finances and feedback, because "social interaction and connectivity have a positive impact on the success of a campaign" (Kaur \& Gera, 2017, 768). Platforms like Kickstarter ${ }^{1}$ or Indiegogo ${ }^{2}$ recommend the project initiators to take some time in advance in order to grow social media presence, to engage with the online community, attract followers that can back the project and maintain a good relationship with them during and after finalizing the crowdfunding campaign.

Even if at a global level crowdfunding become popular and easy to access through dedicated platforms, in Romania there is still a lack of awareness on this topic having under five crowdfunding platforms created and maintained. For sure the level of development it is linked with the development of a proper legislation at country level, an initiative started in Romania in $2015^{3}$ and still under debate. The author was interested to see how it is developed the crowdfunding segment in Romania and analyzed how sprijina.ro platform, one of the most active in Romania, communicate with the online audience on social media.

\section{Dialogic communication principles}

In order to identify the online users' engagement level in crowdfunding campaign communication, the author will start from dialogic communication definition of Kent and Taylor (1998) as „a way of developing and maintaining relations between organizations and its publics". According to Kent and Taylor, the base of dialogic relationship is represented by the existence of five principles any organi-

1 https://www.kickstarter.com/blog/whats-your-projects-communications-plan, accessed on 14th of April 2020.

2 https://support.indiegogo.com/hc/en-us/articles/205183447-Promote-Your-Campaign-with-SocialMedia, accessed on 14th of April 2020.

3 http://www.cdep.ro/pls/proiecte/upl_pck.proiect?idp=14923 accessed on 14th of April 2020. 
zation should be aware of: dialogic loops, useful information, return visit generation, visitor conservation, and ease of interface.

Dialogic loop considers the feedback received from different publics of the organization. By doing so the organization can find out public concerns and integrate those topics in the public relation strategy, being always close to public needs (Kent $\&$ Taylor, 1998, 326). When we refer to an organization, we talk especially about its employees and their attitude in front of different demands received from publics. Kent and Taylor mentioned that employees should be trained to respond and to assume a response time that is acceptable for the public.

The second principle, useful information, points to the health of the web platform. Kent and Taylor emphasize the importance of testing all the steps that has to be completed by publics in order to send a feedback and by organization in order to receive it and answer to it. The organization has to ensure an easy feedback process and has to come back with adequate answer, full of useful information. Regarding the set-up of information on web, Kent and Taylor $(1998,328)$ prioritize the hierarchy and suggest to be included both general and particular information, that may be useful for niche audiences. „In light of hierarchic and structural issues, audience-specific information should be organized such that it is easy to find by interested publics." (Kent \& Taylor, 1998, 328). The information selected to appear on a website should address ,interests, values and different public concerns”, being a bridge that creates and maintain the relationship between an organization and its publics. When publics find the information useful, updated and easy to get, they will most probably be satisfied and will come back.

This is the third principle of dialogic communication, generating return visit. When adding new information on site, updating the existing one or creating sections that are always changing, the online audience will be interested to return and will have the conditions needed for a dialogic relationship with the organization. „Frequently asked questions, easily downloadable or mailed information, technical or specialized information that can be requested by regular email or electronic mail and referral services or links to local agencies or information providers" will improve the online audience experience and make them to return.

The fourth principle, ease of interface, refers to how easy the online audience access the web interface and how fast they find the needed information. The way people interact with the online website leaves a first impression regarding the organization. The same happens when people evaluate the information available: if it is useful, they will be open to dialogue. If the information only serves marketing and advertising purposes without having in mind the audience or if the website has too many information being hard to find the one needed, then it will leave a negative impression on the audience.

The last principle, visitor conservation, refers to how we lead the audience by using hyperlinks: inside the website or on other websites. "Once your audience 
leaves your site on a "link", s/he may never get back." (Kent \& Taylor, 1998, 330). These five principles offer guidance for organizations in order to encourage relationships with publics by "developing web pages, structuring content and organizing information” accordingly (Kent \& Taylor, 1998, 331).

\section{Online engagement}

Taylor and Kent $(2014,384)$ continue the study regarding the dialogic principles and position engagement within the dialogue theory. They explain that "engagement it is both an orientation that influences interactions and the approach that guides the process of interactions among groups". When discussing about dialogic communication in social media networking sites like Facebook we should have an adapted definition of engagement. Evans \& Cothrel $(2014,12)$ highlight that the level of participation represents the difference between engagement in a traditional media and engagement on social web: "customers or stakeholders become participants rather than viewers." In addition, they explain that by offering their time and energy, customers have a direct impact in businesses. This is why the organization needs to "listen, engage, understand and respond directly, specifically, individually and measurably through active conversation". (Evans \& Cothrel, 2014, 12). In order to establish the levels of engagement, Evans and Cothrel $(2014,23)$ propose a hierarchy (Figure 1):

1. consumption - the audience is engaged when downloading, reading, watching or listening online something offered by the organization. People can read or download articles, listen podcast, view videos with recommendations regarding different products or services.

2. creation - people can engage more by uploading photos or videos, commenting on posts, asking questions or by sharing what they are doing in a post. Facebook photos or videos uploaded by the online community, comments or questions asked will be framed in this level of online engagement.

3. curation - refers to the act of rating, reviewing, classifying or even commenting on content contributed by others. Usually this level of engagement it is representative for "people who are regular users and care about the quality and usefulness of information" (Evans \& Cothrel, 2014, 20). By doing this action, the content it is classified and become more useful for the community.

4. advocate - users tend to co-create, recommend and defend the organization and it is the highest level of engagement in relation with organizations.

The existing literature (Lovejoy \& Saxton, 2012; Evans \& Cothrel, 2014; Kim \& Yang, 2017; Stetka et al., 2018; Thelen \& Linjuan Men, 2018; Jarreau et al., 2019; Sahly et al., 2019; Djerf-Pierre et al., 2019) shows engagement from two perspectives: top-down and bottom-up. The "top-down" approach refers to messages sent by the organization in social media that can stimulate the relationship with differ- 


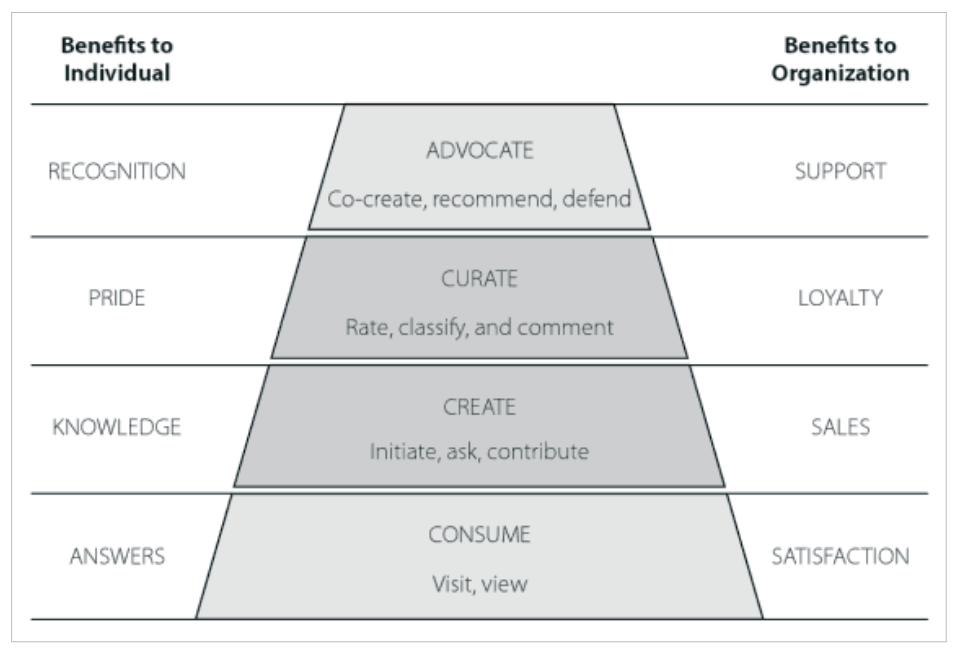

Figure 1. Hierarchy and benefits of engagement (Evans \& Cothrel, 2014, 23).

ent audiences. The "top-down" approach focuses on messages created and published by owners of social media accounts. The "bottom-up" approach includes all reactions received from users, comments, emoticons or redistribution of content created by organization. Stetka et al. $(2018,3)$ mention that „social networks as Facebook, Instagram, Twitter or YouTube offer the opportunity for social actors not just to promote and communicate (...), but also to instantly obtain a quantifiable proof of their users' involvement in the online campaign through social buttons (appreciation, distribution, redistribution / retweet) or through comments."

\section{Crowdfunding}

Crowdfunding is a new way of financing business or cultural ideas or projects different than using the traditional method by lending money from banks. At the European level crowdfunding gained a lot of trust from crowds willing to support and invest in different types of projects and attracted 10.4 billion $^{4}$ euros as of 2017, excluding the UK. France and Germany are the most developed countries in this sector, followed by Netherlands, Italy and Finland. Romania raised over 10.3 million euros of funding in 2017 and ranked on the $23^{\text {rd }}$ position ${ }^{5}$, up 4 positions compared to previous year.

Crowdfunding helps innovators to bring their ideas to life or to get feedback about their projects directly from their target audience. Mollick \& Robb $(2016,2)$

4 https://www.statista.com/statistics/412255/europe-market-size-alternative-finance/, accessed on 20th of April, 2020.

5 https://p2pmarketdata.com/crowdfunding-europe/, accessed on 20th of April, 2020. 
define crowdfunding as "the efforts by entrepreneurial individuals and groups cultural, social, and for-profit - to fund their ventures by drawing on relatively small contributions from a relatively large number of individuals using the internet, without standard financial intermediaries." So, instead of taking the whole amount of money from banks or other financial authorities, project initiators are trying to raise the financial target from many people accessing internet, sometimes totally unknown, attracted by the idea proposed. Start-ups or young creators without an extended personal network have now the possibility to attract supporting crowds, future testers or real long-term customers.

One important differentiation between traditional fundraising and crowdfunding needs to be highlighted: in fundraising actions are taking place especially offline while in crowdfunding there are always intermediated by an online platform. According to Cambridge Dictionary ${ }^{6}$, fundraising means "the act of collecting or producing money for a particular purpose, especially for a charity", while crowdfunding ${ }^{7}$ represents ,the practice of getting a large number of people to each give small amounts of money in order to provide the finance for a business project, typically using the internet". The access to internet plays an important role, as all the crowdfunding efforts and communication actions are developed exclusively on online crowdfunding platforms.

Schwienbacher and Larralde $(2012,4)$ define crowdfunding as "an open call, essentially through the Internet, for the provision of financial resources either in form of donation or in exchange for some form of reward and/or voting rights in order to support initiatives for specific purposes." In crowdfunding there are three main actors: project initiator / founder, backer/funder and platform (Belleflamme et al., 2015). Until now the consumer was taken into consideration at the end of the development process of a product or service. Since internet fast evolution the digital user is treated as a "co-decision-maker". (Gierczak et al., 2016, 7). This different relation with the consumers requires deep changes through all the business model.

The existing literature (Schwienbacher and Larralde, 2012; Belleflamme et al., 2015; Mollick, 2014) highlights four crowdfunding financial models depending on the return type to backers (Gierczak et al., 2016):

5. Reward based crowdfunding - the platform asks the project initiator to offer non-financial rewards for backers supporting its project. He can offer an invitation to a launch event, a demo kit of the product, the possibility to test the product/service in advance or just a thank you note handwritten.

6. Donation crowdfunding - the project initiator asks for financial help without offering something in return. This practice it is most used for social causes like charity, medical reasons, natural disasters, etc.

6 https://dictionary.cambridge.org/dictionary/english/fundraising, accessed on 12th of February, 2020.

7 https://dictionary.cambridge.org/dictionary/english/crowdfunding, accessed on 12th of February, 2020. 
7. Lending crowdfunding - the project initiator will receive money from backers, and in the end backers' credit will be repaid plus interest.

8. Equity crowdfunding or crowdinvesting - project initiator offers shares or revenue share to all backers supporting its project.

Regarding reward-based crowdfunding, there are two types of financing mentioned by Cumming et al. (2015): all-or-nothing (AON) model or fixed model and keep-it-all (KIA) also known as flexible model. When the project initiator chooses to develop an all-or-nothing crowdfunding campaign, he sets a funding target. If the target is reached or exceeded by the end of the campaign, the project initiator will receive the whole amount of money minus the platform fee, otherwise all of money will be returned to backers. In case of keep-it-all type of campaign, the project initiator creates a goal for the campaign and, at the end of it, he receives the money no matter what percentage of the financial target has been achieved.

In order to develop a successful crowdfunding campaign, platforms recommend some steps to be followed. For example, Sprijina.ro offers a weekly calendar ${ }^{81}$ with day to day recommended activities that include how to set up the team, how to present the project on crowdfunding platforms, set the rewards for backers, attract the online crowd, alert the media, promote the idea and obtain finance from backers. Another suggested topic when launching the crowdfunding project is to constantly update the initiator existing network with news regarding project development. As Beier and Wagner $(2015,7)$ are mentioning "the number of Facebook friends of project initiators are seen as a success factor in crowdfunding campaigns". Also sprijina.ro platform suggests to project initiators to offer answers to comments received from the online crowd arguing that listening to the crowd and being "proactively rather than reactively"9 represent important steps in creating and maintaining trust relationships with it. "The relationship quality as developed by online communication (...) influences the motivation of potential supporters to spend more money on a project" (Beier \& Wagner, 2015, 4). So, we expect to have a direct link between the quality of project (measured in the quality of photos and videos published, the number of spelling errors, etc.), the quality of communication (the existence of a communication strategy, the number of updates, the activation of the existing online social network, etc.) and the success of the campaign. This aspect it is also highlighted by Mollick \& Robb (2016, 2): "Crowdfunding success appears to be linked to project quality, in that projects that signal a higher quality level are more likely to be funded, while a large number of friends on online social networks are similarly associated with success."

8 https://www.sprijina.ro/cum-functioneaza, accessed on $15^{\text {th }}$ of May 2020.

9 https://www.gov.uk/government/publications/understanding-crowd-behaviours-documents, accessed on 15th of May 2020. 
Following the two aspects (AON/KIA) the author realized Table 1 for the crowdfunding platforms in Romania and the type of crowdfunding model it allows. The author has identified at least 7 Romanian crowdfunding platforms, the oldest one being started in 2012 .

Table 1. Romanian crowdfunding platform index - type of crowdfunding model

\begin{tabular}{lcc}
\hline \multicolumn{1}{c}{ Name of platform } & KIA & AON \\
\hline Bursabinelui.ro & $\sqrt{ }$ & \\
Crestemidei.ro & & $\sqrt{ }$ \\
Multifinantare.ro & & $\sqrt{ }$ \\
Potsieu.ro & & $\checkmark$ \\
Sprijina.ro & $\sqrt{ }$ \\
Startarium.ro & & $\sqrt{ }$ \\
We-are-here.ro & $\sqrt{ }$ \\
\hline
\end{tabular}

The majority of existent platforms in Romania apply AON model, but there are also platforms that leave the decision to the initiator, offering both funding models. By proposing an AON crowdfunding campaign, entrepreneurs signal also bigger capital expectations and propose more reward levels than KIA (Vidrașcu, 2018, 2). Unfortunately, during the last 4 years, 2 of the most important crowdfunding platforms in Romania have stopped their activity. Crestemidei.ro, an AON platform, has announced in 2018, after 6 years of crowdfunding activity, that it will unable to function due to lack of financial support for platform administrative costs. The other platform, we-are-here.ro, started in 2013, announced at the end of 2019 that it is looking for a new ownership able to invest in platform. The lack of financial resources is not the only problem in the development process of crowdfunding in Romania. The lack of legislation on this topic and the financial exclusion context have also a big influence. In 2014 the Romanian Young Entrepreneurs Association (PTIR) initiated a draft ${ }^{10}$ for crowdfunding legislation, but it was never adopted by the Government. Regarding financial exclusion, in 2016 Romania was the European country with the highest "no-account" rate having $39.2 \%$ adults without access to formal financial services like bank account ${ }^{11}$. These statistics exert a direct influence on the trust and adoption of online financial services by the population, crowdfunding functioning only with online payments. For this research the author has chosen to analyze sprijina.ro platform due to the fact that has the biggest number of active projects, attracts backers and financial resources.

10 https://www.ptir.ro/2015/05/lege-privind-dezvoltarea-finantarilor-participative-crowdfunding/, accessed on 15th of May 2020.

11 https://www.wsbi-esbg.org/press/latest-news/Pages/Close-to-40-million-EU-citizens-outsidebanking-mainstream.aspx, accessed on 15th of May 2020. 


\section{From business to social business on Facebook}

When people are discussing about crowdfunding, they have in mind most of the time the main benefit, that it is a source of alternative financing (Cumming et al., 2015; Mollick \& Robb, 2016). In addition, crowdfunding represents also a way to test the market appetite regarding a business idea (Schwartz, 2015). Moisseyey (2013, 10) mentions that crowdfunding it is more than just a source of funding. "It is a research tool. By estimating how many people backed projects as well as just 'liked' them in Facebook, entrepreneurs can evaluate potential demand for their ideas." If they like the idea, it is most probably they will search more information about it before sharing to their online social networks.

Moisseyey $(2013,30)$ analyzed the connection between likes on Facebook and the success of crowdfunding campaigns and suggests that 'likes' represent "hard currency" in crowdfunding because have a direct impact in the total number of backers and also in achieving the financial goal. "People with powerful social media profiles can get more 'likes' for their crowdfunding projects and more 'likes' can bring more money" Moisseyey (2013, 31). Having the financial goal in mind, project initiators can organize a promotional campaign or can directly ask family and friends to give them a like, to spread the information and show online social approval. This research focuses on how much do crowdfunding platforms help to spread the information regarding projects they host and to create a relationship with the online audience through social media because, as Evans \& McKee (2010) mention the most important aspect in social business is customer engagement. While traditional advertising goals are exposure and impression, social media allows the achievement of collaboration between business and consumers." Greater initial contributions will have a positive effect on later contributions as the information on prior activity of consumers affects later potential supporters (Moisseyey, 2013, 12). So, it is important how the online communication starts in order to set the ground for a successful campaign.

\section{Methodology}

The author selected and analyzed 35 sprijina.ro Facebook posts between 2017 and 2019, gathering in total more than 1316 likes, 187 shares and 11 comments. At the time this research article was conducted the page had around 9.500 followers. In order to answer the research question regarding the use of dialogic communication principles, the author will use both the "top-down" and "bottom-up" approach. The "top-down" approach will identify what sprijina.ro is posting on Facebook for its followers, how often, on which subjects, which is the tone of voice, if it contains photos, videos or hyperlinks, etc. By using the "bottom-up" approach the author will analyze user reactions to official posts and the level of audience engagement according to Figure 1. 
The content analysis method has been used to find out if Facebook is used by the Romanian crowdfunding platform sprijina.ro as a tool for dialogic communication with online audience, to encourage them to interact through like, share or comment and to attract their attention and finances to the platform. The corpus, represented by Facebook posts of sprijina.ro ${ }^{12}$ official account during 2-year time span (20172019), will be analyzed by using the following coding scheme:

- Type/Format of post - if the post included different formats like text, video, photo, emoticons or other graphic representations then was coded with " 1 ". If not included, was coded with " 0 ".

- Type of content: owned content was coded with 1 , while shared content from other sources was coded with 2.

- Topic of post: researchers looked through the sample of posts and developed 3 categories: (1) promoting platform, (2) promoting projects, (3) post dedicated to/about online community.

- Level of online public engagement: number of likes and other reactions (share, comment, views) were measured.

- Tone of comments was coded as " $1=$ positive", " $2=$ negative", " $3=$ neutral".

- Dialogic principles - in line with previous studies (Thelen \& Linjuan Men, 2018) the author excluded the "ease of the interface" because all posts are displayed on the same platform, Facebook. The rest of dialogic principles remain the same: dialogic loops, useful information, return visit generation, visitor conservation. For each the author identified relevant elements to be searched for. The inclusion of each element was coded with " $1=y e s$ " and " $0=$ no".

- Dialogic loop - contact email address; call to subscribe to sprijina.ro newsletter, voting, encouraging people to ask for information through Facebook messenger or comments, answer/reply to user's comments, reactions to user comments (like/emoticons), the use of hashtags.

- Useful information - targeting the audience, explaining the mission, describing the project/service/product, calendar with events planned, links to other news from the same area of interest (to NGO's, websites, authorities, etc.).

- Return visit generation - the existence of FAQ/Q\&A section, the explicit ask for users to come back/to become follower/friends.

- Visitor conservation - keeping visitors engaged by using photos, videos, text, graphics. links to the crowdfunding dedicated page; link to other social networks of the project.

In addition, descriptive statistics (financial goal, type of campaign, project category, number of backers, city of the project initiator, number of projects submitted by the same initiator) regarding the campaigns selected to be promoted on sprijina.ro Facebook page will be analyzed.

12 https://www.facebook.com/sprijina.ro/ accessed on 14th of May 2020. 


\section{Results}

During analysis the author identified a lack of information regarding email contact address. There were no opportunities for audience to vote ideas/give feedback or to subscribe to sprijina.ro newsletter. Also, the viewers were not encouraged to ask for more information through Facebook messenger or comments. By missing these actions, sprijina.ro Facebook account received a reduced number of likes, shares and comments, being difficile to create a dialogic context. After excluding the outliers (the largest and the smallest value), the trimmed mean for one post is represented by 22 likes, 0.59 comment and 0.1 shares received from the online audience. Out of total number of comments, $66 \%$ had a neutral tone of voice, $23 \%$ were positive and $14 \%$ negative. Weak activity regarding reactions to user's comments $(14 \%)$ or comments between users (3\% of posts) shows that sprijina.ro is not using the dialogic loop principle in order to create the context for a better online engagement with audience. The only positive aspect observed was the use of hashtags like "\#HaiPeSprijina" and "\#SprijinaSiTu", used to aggregate the online content in $91 \%$ of posts.

Regarding the level of useful information when communicating online with the audience, sprijina.ro described the project/service/product (94\%) and the mission of the project team (80\%) in the majority of posts. The focus was not on describing the target audience (9\%), presenting a calendar with future events (6\%), nor on posting related news from press or from other authorities in order highlight projects benefits in front of the audience.

When discussing about visitor conservation the majority of posts contain text $(97 \%)$ and photos $(86 \%)$, a quarter $(26 \%)$ contain emoticons and just a few of them have graphic representations (11\%) and videos (3\%). Also, $86 \%$ of posts had a direct link to crowdfunding dedicated page. Sprijina.ro did not explicitly request users to come back on page from time to time in any of published posts. Also, the absence of FAQ section from sprijina.ro Facebook account suggest that sprijina.ro did not have a return visit strategy when communicating with followers.

Regarding the type of content, the total number of posts represent owned posts $(100 \%)$, not shared ones.

The author identified 3 main topics: the first one talks about how the platform is functioning (3\%), the second one promotes projects they host online and ask for financial support (94\%) and the last one include posts dedicated to the online community (3\%). The online audience showed high engagement when reading posts dedicated to the online community, giving back the biggest number of likes and comments. Unfortunately, this type of post was not representing the majority.

As we can see in Figure 2, the most used words are talking about the invitation on the platform, promoting the platform, nothing about the audience. 


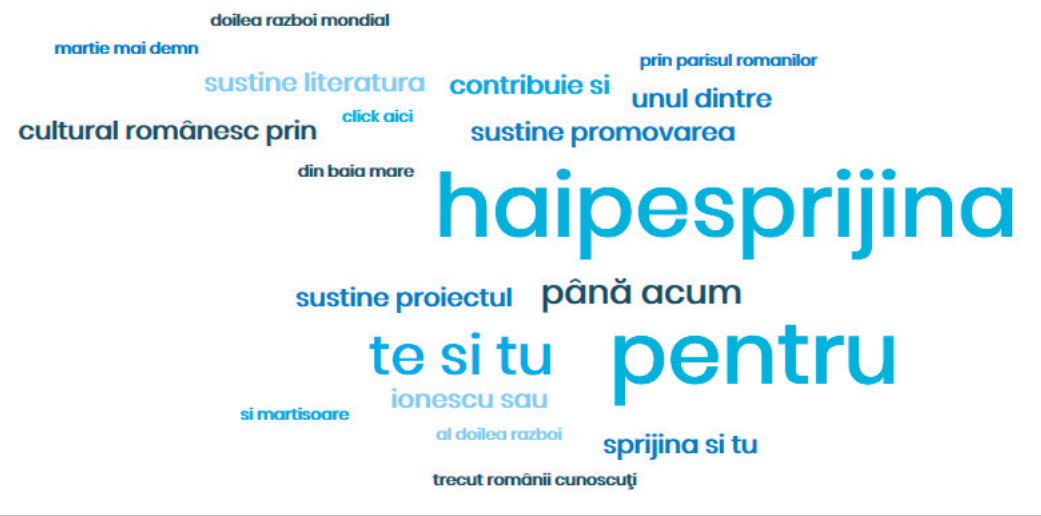

Figure 2. Word cloud representing most used words on Facebook posts (the English translation is available in Annex.1)

\section{Conclusion}

Even if online communication channels are increasing their importance as noted by ECM 2014, it seems that Romanian crowdfunding platforms (as is the case of sprijina.ro) still has to learn and develop communication strategies in order to create a dialogic context, to communicate better and attract followers. Moreover, in order to have customers or stakeholder active participants in the communication process platforms need to have a sustained communication, without big amounts of time of silence. The number of posts has to be stable and increasing year after year. Sprijina.ro has been unstable, having only 4 posts in 2017, 24 posts in 2018 and then just 7 posts in 2019. In total the account published information about 32 crowdfunding campaigns (the rest to 35 were reminders or posts without connection to a specific campaign), a low percentage if we consider the 162 campaigns launched on sprijina.ro platform during the 2 years span. In order to raise audience engagement, platforms have to use every communication opportunity they have or even to create opportunities.

In addition, in regard of the elements highlighted by Evans \& Cothrel $(2014,12)$ regarding engagement, like active engage and respond to comments received from users, the platform analyzed was unable to create the context for an active conversation by neglecting these actions. The study also shows that, in order to create a relationship and maintain it with the online audiences, platforms should integrate more posts addressed to the online community, not just post that are promoting projects and are asking for financial support. Next step for this research could be represented by developing a similar analyze for one big European platform in order to see differences and best practices in communication with online audiences. 
In the end, based on these findings could be created short tutorials (video or text) addressed to crowdfunding platform owners in order to raise awareness about the importance of creating dialogic context for online audience when promoting projects online on social media.

\section{References}

1. Beier, M., \& Wagner, K. (2015). Crowdfunding success: A perspective from social media and e-commerce. In Proceedings of the $36^{\text {th }}$ International Conference on Information Systems: Exploring the Information Frontier (pp. 634-655). Association for Information Systems, Fort Worth, TX.

2. Belleflamme, P., Omrani, N. \& Peitz, M. (2015). The economics of crowdfunding platforms. Information Economics and Policy, 33, 11-28.

3. Cumming, D., Leboeuf, G., \& Schweinbacher, A. (2015) Crowdfunding models: keep-itall vs. all-or-nothing. SSRN Electronic fournal.

4. Djerf-Pierre, M., Lindgren, M. \& Budinski, M. A. (2019). The role of journalism on YouTube: audience engagement with 'superbug' reporting. Media and Communication, 7(1), 235-247.

5. Evans, D. \& McKee, J. (2010) Social media marketing: the next generation of business engagement. Indianapolis, Indiana: Wiley Publishing.

6. Evans, D. \& Cothrel, J. (2014). Social customer experience: Engage and Retain Customers through Social Media. Indianapolis, Indiana: John Wiley \& Sons.

7. Gierczak, M. M., Bretschneider, U., Haas, P., Blohm, I. \& Leimeister, J.M. (2016). Crowdfunding: outlining the new era of fundraising. In Dennis Bruntje, D., Gajda, O. (Eds.), Crowdfunding in Europe. State of the art in theory and practice (pp. 7-24). Springer.

8. Jarreau, P. B., Dahmen, N. S. \& Jones, E. (2019). Instagram and the science museum: a missed opportunity for public engagement. fournal of Science Communication, 18(2), $1-22$.

9. Kaur, H. \& Gera, J. (2017). Effect of social media connectivity on success of crowdfunding campaigns. Procedia Computer Science, 122, 767-774.

10. Kent, M.L. \& Taylor, M. (1998). Building dialogic relationships through the WorldWideWeb. Public Relations Review, 24(3), 321-334.

11. Kent, M.L., \& Taylor, M. (2014). Dialogic engagement: Clarifying foundational concepts, Journal of public relations research, 26, 384-398.

12. Kim, C., \& Yang, S.U. (2017). Like, comment, and share on Facebook: How each behavior differs from the other. Public Relations Review, 43(2), 441-449.

13. Lovejoy, K. \& Saxton, G.D. (2012). Information, community, and action: how nonprofit organizations use social media. fournal of Computer-Mediated Communication, 17(3), 337-353.

14. Moisseyey, A. (2013). Effect of social media on crowdfunding project results, 10. Dissertations and Theses from the College of Business Administration. Paper 39.

15. Mollick, E. (2014). The dynamics of crowdfunding: An exploratory study. Fournal of Business Venturing, 29(1), 1-16. 
16. Mollick, E. \& Robb, A. (2016). Democratizing innovation and capital access: the role of crowdfunding. California Management Review 58(2), 2-24.

17. Sahly, A., Shao, C. \& Kwon, K. H. (2019). Social media for political campaigns: an examination of Trump's and Clinton's frame building and its effect on audience engagement. Social Media + Society, 5(2), 1-13.

18. Stetka, V., Surowiec, P. \& Mazak, J. (2018). Facebook as an instrument of election campaigning and voters' engagement: Comparing Czechia and Poland. European fournal of Communication, 34(2), 1-20.

19. Thelen, P.D. \& Linjuan Men, R. (2018). Strategic use of Facebook for public engagement in higher education institutions. Public Relations fournal, 12(2), 1-27.

20. Schwartz, A. A.; (2015). The nonfinancial returns of crowdfunding. Review of Banking and Financial Law, 34(2), 565-580

21. Schwienbacher, A. \& Larralde, B. (2012). Crowdfunding of small entrepreneurial ventures. Oxford Handbook of Entrepreneurial Finance, Oxford University Press, 5-23.

22. Vidrascu, R. (2018). The Dynamics of Crowdfunding in a Frontier Market: An Exploratory Research on Romania. European fournal of Marketing and Economics, 1(2), 7-17.

\section{Online sources}

23. Dictionary.cambridge.org - https://dictionary.cambridge.org/

24. European Communication Monitor 2014 - https://www.communicationmonitor.eu/20 14/06/13/ecm-european-communication-monitor-2014-social-mobile-communicationmedia-technologies-job-satisfaction-gender-excellence/

25. Gov.uk - https://www.gov.uk/government/publications/understanding-crowd-behavio urs-documents

26. Indiegogo.ro

27. Kickstarter.ro

28. P2pmarketdata.com - https://p2pmarketdata.com/crowdfunding-europe/

29. Ptir.ro - https://www.ptir.ro/2015/05/lege-privind-dezvoltarea-finantarilor-participati ve-crowdfunding/

30. Sprijina.ro

31. Statista.com - https://www.statista.com/statistics/412255/europe-market-size-alternati ve-finance/ 


\section{Annex 1}

The translation of the words within the word cloud available in Figure 2

\begin{tabular}{|l|l|}
\hline Romanian & English \\
\hline Doilea razboi mondial & Second world war \\
\hline Martie mai demn & March in dignity \\
\hline Sustine literatura & Support literature \\
\hline Cultural romanesc & Romanian culture \\
\hline Hai pe sprijina & Come on sprijina \\
\hline Sustine proiectul & Support project \\
\hline Contribuie & Support \\
\hline Sustine promovarea & Support promotion \\
\hline Trecut romanii cunoscuti & Well-known Romanians past \\
\hline
\end{tabular}

